\title{
Megaspores from coals of the Triunfo Member, Rio Bonito Formation (Lower Permian), northeastern Paraná State, Brazil
}

\author{
FRESIA RICARDI-BRANCO ${ }^{1}$, MITSURU ARAI ${ }^{2}$ and OSCAR RÖSLER ${ }^{3}$ \\ ${ }^{1}$ Departamento de Administração e Política de Recursos Minerais (DARM), Instituto de Geociências \\ UNICAMP, Cidade Universitaria Zeferino Vaz, Cx. Postal 13083-970 Campinas, Brazil \\ ${ }^{2}$ PETROBRAS/CENPES 21949-900, Rio de Janeiro, RJ, Brazil \\ ${ }^{3}$ CENPÁLEO, Universidade do Contestado, Mafra, SC, Brazil \\ Manuscript received on May 10, 2001; accepted for publication on December 6, 2001; \\ contributed by OSCAR RöSLER*
}

\begin{abstract}
This paper presents the results of a detailed study of megaspores occurring in coal seams of the Triunfo Member, Rio Bonito Formation at Figueira, Paraná State, Brazil. This coal-bearing sequence accumulated in a marine delta system during the Early Permian.

Four species are described and illustrated: Lagenoisporites triunfensis, L. scutiformis, Sublagenicula cf. brasiliensis, and Setosisporites cf. furcatus. Of these, the two species of Lagenoisporites are predominant. Relationships to other megaspore species are discussed; and the temporal and spatial distributions of the four species in the Paraná Basin are documented.
\end{abstract}

Key words: megaspores, Permian, Rio Bonito Formation, Paraná Basin.

\section{INTRODUCTION}

Recent studies of the Rio Bonito paleoflora in the Figueira region revealed abundant megaspores associated with plant megafossils (Ricardi-Branco 1997).

Lagenoisporites triunfensis Arai and Rösler is by far the most abundant megaspore species and has not previously been reported outside its type locality (São João do Triunfo, Paraná State). Another abundant species, L. scutiformis Trindade, is recorded for the second time outside its type locality (Monte Mor, São Paulo State). In the present study, 123 specimens of L. triunfensis and 34 of L. scutiformis were found. Previous studies documented four specimens

Correspondence to: Fresia Ricardi-Branco

E-mail: fcbranco@cwaynet.com.br/fresia@ige.unicamp.br

*Member of Academia Brasileira de Ciências of L. triunfensis (Arai and Rösler 1984); and 20 and 23 specimens of $L$. scutiformis (Trindade 1970, Arai and Rösler 1984, respectively).

The two other, less abundant species identified are Sublagenicula $\mathrm{cf}$. brasiliensis ( 7 specimens) and Setosisporites cf. furcatus (3 specimens). Previous records of these two species show a wide temporal and geographic distribution. For example, they have been recorded from the Monte Mor exposure of the Itararé Subgroup in southeastern Brazil (Trindade 1970) as part of a Late Carboniferous flora. They are also components of Early Permian floras of the Rio Bonito Formation in southern Brazil (Dijkstra 1956, Trindade 1962); e.g., at Barro Branco (Santa Catarina State) and Leão and Candiota coal mines (Rio Grande do Sul State). 


\section{FIGUEIRA REGION: LOCALITY AND GEOLOGY}

The Figueira region is located in southern Brazil, in the northeastern part of Paraná State (Fig. 1). The upper Paleozoic lithostratigraphic succession includes the Upper Carboniferous to Lower Permian Itarare Subgroup sediments overlain by the Lower Permian Rio Bonito Formation (Triunfo and Paraguaçu Members) (Fig. 2) and the Palermo, Irati, Serra Alta, and Teresina Formations (Soares and Cava 1982, Aborrage and Yamamoto 1982, Morrone and Daemon 1985). The megaspores described herein are from the lower part of Triunfo Member, specifically from siltstones immediately overlying the coal bed.

The depositional environment of the coal at Figueira (Soares and Cava 1982, Morrone and Daemon 1985, Della Fávera et al. 1993, Della Fávera and Chaves 1998) is thought to have been related to a delta-plain system wherein extensive swampy areas were covered by vegetation and possibly surrounded by sandy banks. Subsequent change in the drainage regime caused the collapse of the basin and effectively terminated peat deposition.

\section{SOURCE OF THE PALYNIFEROUS SAMPLES}

The megaspore-bearing samples were collected in the coalfields of Companhia Carbonífera do Cambuí (Fig. 1, Table I): Amando Simões mine (AS, well 01 and 06), Slope Plan mine 115 (SP-115), and from the general waste deposit (GWD) of the Amando Simões mine. The megaspores are from the grey siltstones located at the top of the coal seams. Also occurring with the megaspores are carbonized compressions of coniferous leaves, cones, seeds, branches, and microphylls, together with lycophyte shoots and glossopterid leaves.

\section{MATERIALS AND METHODS}

The samples were treated initially with $50 \%$ Schulze reagent for 5 to 6 days. The megaspores were retrieved from the residues using a fine paintbrush and then rinsed with distilled water. They were then immersed in a $20 \%$ solution of hydrofluoric acid for 24 hours in order to remove adherent mineral mat- ter. After further thorough washing to neutrality, the specimens were left to dry at room temperature $\left(20-30^{\circ} \mathrm{C}\right)$

The 16 samples (6 from SP-115 mine, 5 from AS, and 5 from GWD) yielded a total of 352 megaspores. These were mounted on slides for observation by stereoscopic binocular microscopy.

Selected specimens were studied and photographed with a scanning electron microscope (SEM) in Centro de Pesquisas e Desenvolvimento Leopoldo A. Miguez de Mello (CENPES-PETROBRÁS), Rio de Janeiro, RJ.

The palyniferous samples are housed in the scientific collections of the Instituto de Geociências da Universidade de São Paulo (IG/USP), São Paulo, Brazil. The catalogue numbers are as follows: GP/3T 2137, 2138, 2143, 2146, 2147, 2155 , $2156,2158,2160 \mathrm{~b}, 2162,2165,2167,2182,2185$, 2189 , and 2204c.

\section{SYSTEMATIC PALYNOLOGY}

Anteturma Megasporites Pant, 1962

Turma Triletes Reinsch emend. Potonié and Kremp, 1954

Suprasubturma Lagenotriletes Potonié and Kremp, 1957

Subturma Gulati Bharadwaj, 1957

Genus Lagenoisporites Potonié and Kremp, 1955

\section{Lagenoisporites triunfensis}

Arai and Rösler, 1984

Figure 3 (pictures 1-5) and Figure 5 (pictures 1,2). Samples: GP/3T 37, 2143, 2146, 2147, 2155, 2156 , $2158,2160 b, 2162,2165,2167,2182,2185,2189$, and $2204 \mathrm{c}$.

Description: Megaspores with gula. Rounded in polar compression; oval in lateral compression and slightly prolate. Gula pyramidal with acute apex. Straight or slightly undulatant, thick trilete rays. Arcuate ridges well-defined, confluent with the trilete rays, and marked by prominent lateral auriculae. Contact faces psilate, distal surface baculate.

Dimensions: a) Equatorial view: 1267 (2060) 2689 $\mu \mathrm{m} \times 1044$ (1663) $2133 \mu \mathrm{m}$. Gula 556 (814) 1333 


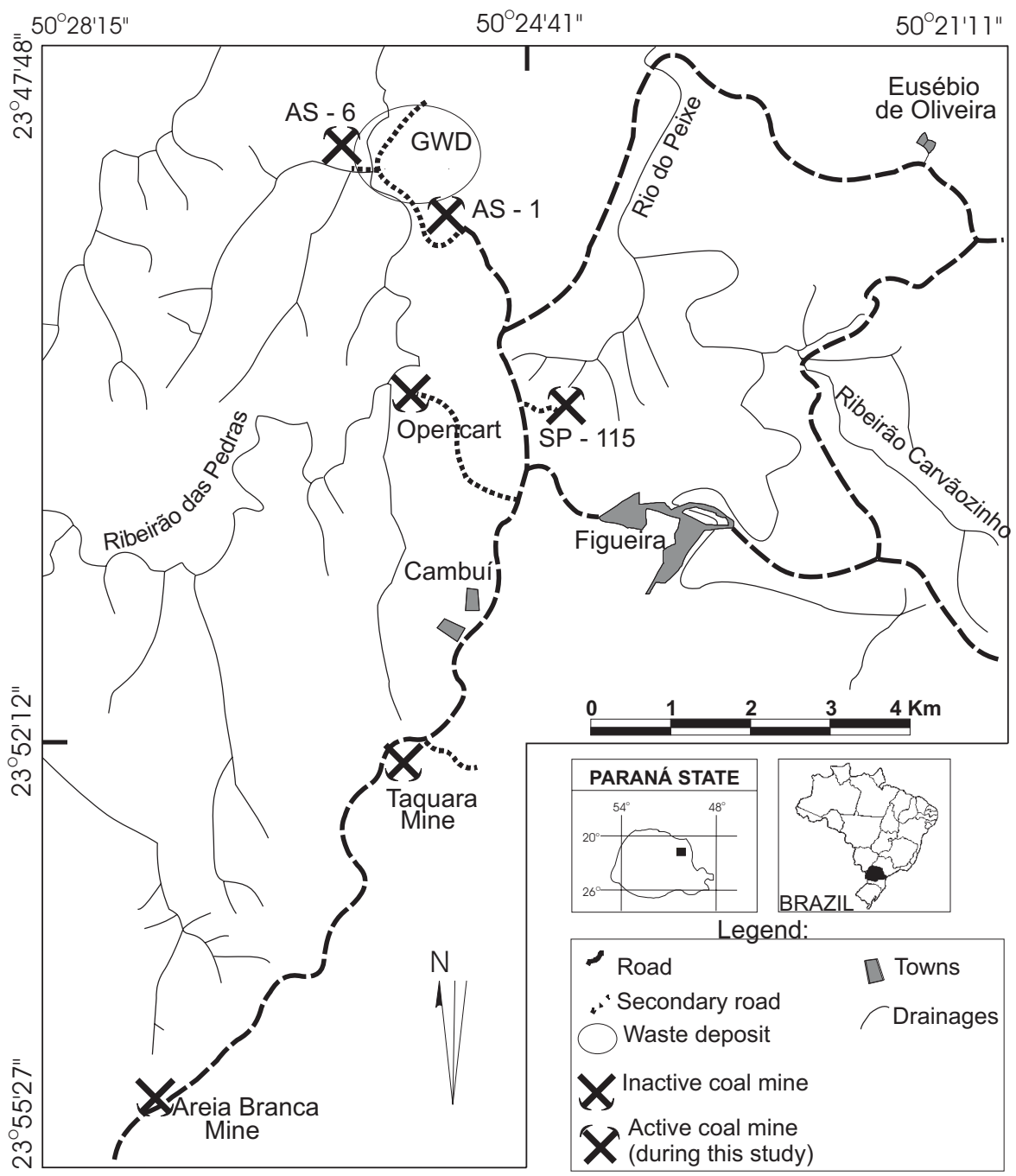

Fig. 1 - Map of the Figueira region, Paraná State, showing locations of the Amando Simões mine (AS-1 and AS-6), the Slope Plan mine 115 (SP-115) and the General waste deposit (GWD). Source: Carta do Brasil 1970 - IBGE - Folha Figueira, PR.

$\mu \mathrm{m} \times 800$ (1114) $1606 \mu \mathrm{m}$. Trilete rays 578 (836) $1111 \mu \mathrm{m}$. Arcuate ridges 844 (1038) $1222 \mu \mathrm{m}$. Auriculae 156 (236) $400 \mu \mathrm{m} \times 133$ (220) $312 \mu \mathrm{m}$.

b) Polar view: Equatorial diameter 1133 (1646) $1955 \mu \mathrm{m}$. Gula $444(592) 756 \mu \mathrm{m} \times 711(895)$ $1000 \mu \mathrm{m}$. Trilete rays $556(698) 778 \mu \mathrm{m}$. Auriculae 178 (222) $267 \mu \mathrm{m} \times 133(224) 356 \mu \mathrm{m}$.
Discussion: One hundred and twenty-three whole megaspores were observed, 96 of them compressed laterally (Fig. 3, pictures 1, 2, 4; Fig. 5, picture 1). The other 27 specimens are proximo-distal compressions (Fig. 3, picture 3).

Among the specimens examined, 33 had evidently germinated, as indicated by their open gula. These were not measured, as measurements are con- 


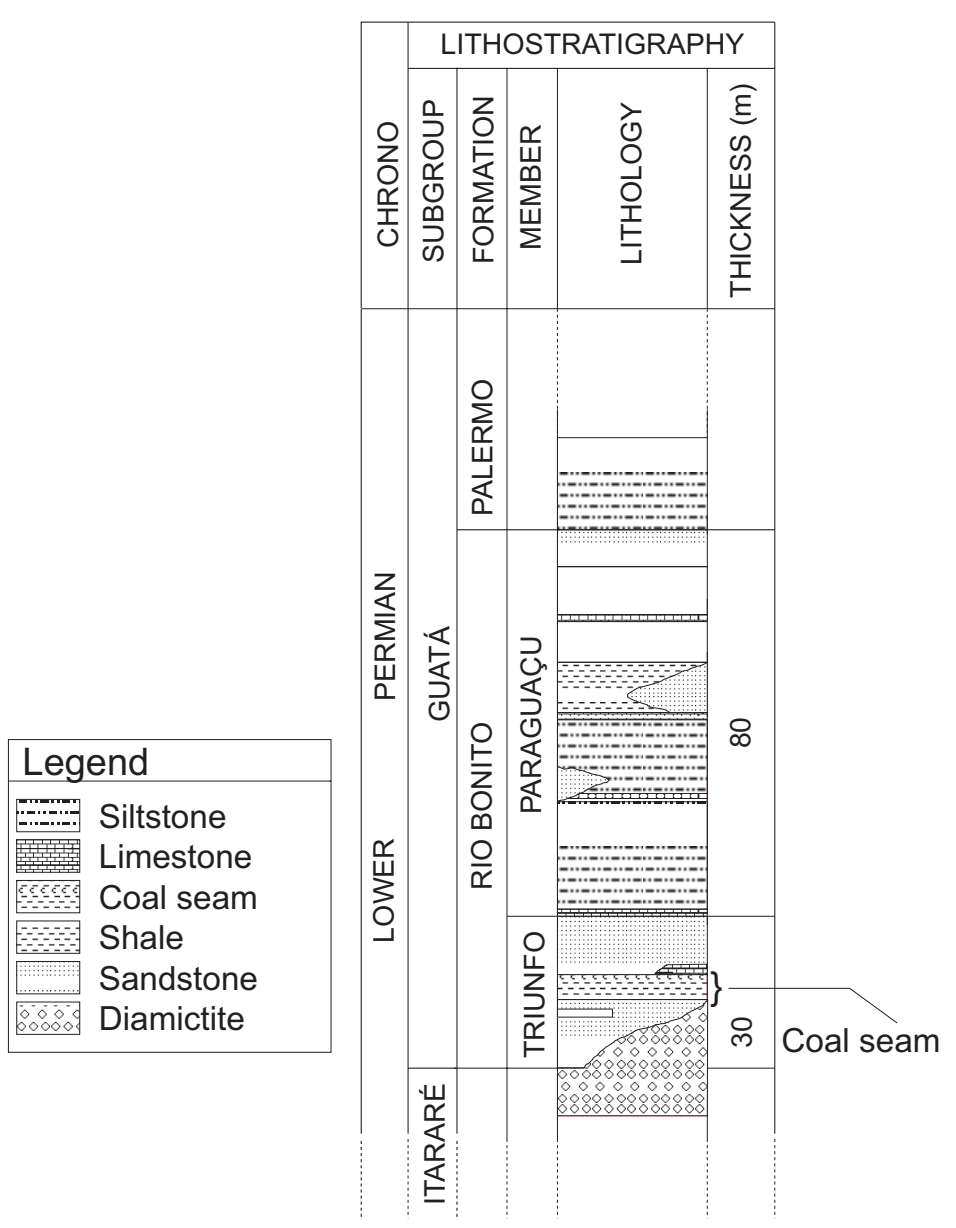

Fig. 2 - Lithostratigraphy of the Rio Bonito Formation in the Figueira region. Modified from: Morrone and Daemon 1985.

ventionally based on specimens with closed gula. The latter account for approximately $67 \%$ of the specimens studied.

The dimensions of laterally compressed specimens are typically $2000-2400 \mu \mathrm{m}$ long (49 specimens) and 1400-1800 $\mu$ m wide (54 specimens). The majority of specimens preserved as proximo-distal compressions range between 1400 and $1800 \mu \mathrm{m}$ in equatorial diameter (17 specimens).

The smaller specimens were found among the megaspores of the samples GP/3T 2162 and 2165 (e.g., $956 \mu \mathrm{m}$ long in the latter sample). These are considered aborted forms, following the criterion applied by Dijkstra (1956) to small specimens of Triletes brasiliensis.

All these megaspores are very similar to $L$. triunfensis, previously reported as occuring only at the type locality [i.e., the outcrop of S.J. do Triunfo (Rio Bonito Formation): Arai and Rösler 1984]. The main difference is that the average size of the Figueira specimens is larger (1267-2689 $\mu \mathrm{m} \times$ 1044-2133 $\mu \mathrm{m})$ than typical L. triunfensis (1280$1800 \mu \mathrm{m} \times 1250-1800 \mu \mathrm{m})$. This difference can be explained by the number of specimens measured during this study: i.e., 123 compared with only four studied by Arai and Rösler (1984). Most probably, the differences reflect intraspecific size-variations. Other characters, such as shape, gula, arcuate ridges, 
TABLE I

Occurrence of megaspore species identified, with number of specimens per sample.

\begin{tabular}{|c|c|c|c|c|c|}
\hline $\begin{array}{c}\text { Species/ } \\
\text { Samples } \\
\text { GP/3T }\end{array}$ & Locality & $\begin{array}{c}\text { Lagenoisporites } \\
\text { triunfensis } \\
\text { Trindade }\end{array}$ & $\begin{array}{l}\text { Lagenoisporites } \\
\text { scutiformis } \\
\text { Arai and Rösler }\end{array}$ & $\begin{array}{c}\text { Sublagenicula } \\
\text { cf. S. brasiliensis } \\
\text { (Dijkstra) }\end{array}$ & $\begin{array}{c}\text { Setosisporites } \\
\text { cf. S. furcatus } \\
\text { (Dijkstra) }\end{array}$ \\
\hline 2137 & AS-1 & 1 & & & \\
\hline 2138 & AS-1 & & & 1 & \\
\hline 2143 & SP-115 & 1 & & & \\
\hline 2146 & SP-115 & 7 & 3 & & \\
\hline 2147 & SP-115 & 18 & 9 & 4 & 1 \\
\hline 2155 & AS-6 & 1 & & & \\
\hline 2156 & AS-6 & 5 & 1 & & \\
\hline 2158 & SP-115 & & 1 & & \\
\hline $2160 b$ & GWD & 30 & 4 & & \\
\hline 2162 & GWD & 6 & 3 & & \\
\hline 2165 & GWD & 24 & 6 & 2 & \\
\hline 2167 & GWD & 2 & 2 & & \\
\hline 2182 & GWD & 2 & 1 & & 2 \\
\hline 2185 & GWD & 1 & & & \\
\hline 2189 & GWD & 13 & 2 & & \\
\hline $2204 c$ & GWD & 12 & 2 & & \\
\hline Total & & 123 & 34 & 7 & 3 \\
\hline
\end{tabular}

Key to locates: slope plain mine 115 (SP-115); Amando Simões well 1 (AS-1) and well 06 (AS-6); general waste deposit (GWD).

ornamentation, etc., justify inclusion of the present specimens in Lagenoisporites triunfensis. Thus the Figueira region is the second site from which this species has now been reported.

L. triunfensis shows many similarities to $L$. scutiformis Trindade. However, salient differences lie in the ornamentation of the distal hemisphere. In $L$. triunfensis it is apiculate-capillate (Arai and Rösler 1984), but is smooth in L. scutiformis (Trindade 1970). Although size is considered a valid differential parameter, its validity decreases as the range of variation increases, as in L. triunfensis. In this case, size cannot be used as the sole criterion for distinguishing L. triunfensis from L. scutiformis. In other words, distal ornamentation remains the prime means of differentiating these two species.
Dybová-Jachowicz et al. (1979) proposed a novel classification of gulate megaspores, based on the type of gula, According to their scheme, many species formerly included in the genus Lagenoisporites were reallocated to a new genus Sublagenicula, which includes many of the subgulate megaspores. According to these authors, L. triunfensis features an anguligula, typical of the genus Auritolagenicula, which ranges from Upper Devonian through Namurian A. In contrast to Lagenoisporites, Auritolagenicula typically exhibits a thick exine which is more or less densely ornamented. The Figueira specimens do not comply with this system, and accordingly we prefer to retain the specimens described above in Lagenoisporites.

L. triunfensis shows no resemblance to other 


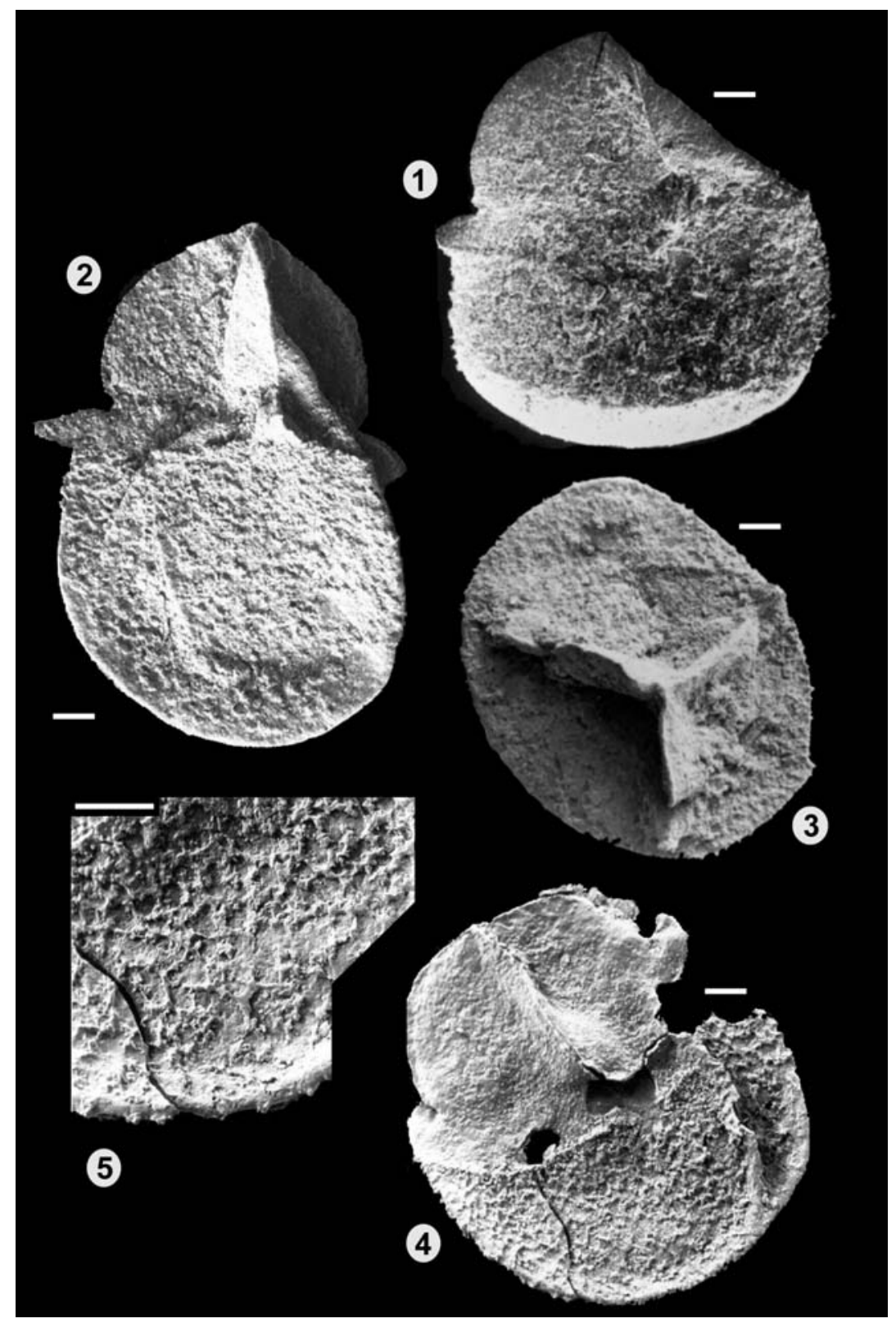

Fig. 3 - Megaspores Lagenoisporites triunfensis: 1. Lateral compression (GP/3T 2160b); 2. Distal-lateral compression (GP/3T 2160b); 3. Polar compression, proximal view (GP/3T 2165); 4. Lateral compression (GP/3T 2160b); 5. Magnification of fig. 4 showing ornamentation. Scale bar $=200 \mu \mathrm{m}$.

species of megaspores that have been described from either Argentina or Brazil. However, it shows similarities, in shape and type of gula, to certain specimens that were described from the Namurian of the
Illizi Basin (Candilier et al. 1982) and were included in Auritolagenicula. When comparing A. spinulata Candilier, Coquel and Loboziak and A. bacculata Candilier, Coquel and Loboziak with the specimens 
studied herein, we can observe several differences relating to size and sculpture of the contact faces and of the distal hemisphere. Concerning size, the specimens of A. spinulata $(1360-1800 \mu \mathrm{m} \times 1240-1680$ $\mu \mathrm{m})$ and A. bacculata $(800-1100 \mu \mathrm{m} \times 700-800$ $\mu \mathrm{m})$ are smaller than those of L. triunfensis. The ornamentation of $A$. spinulata consists of long spinules that cover both the contact faces and the distal hemisphere, while the baculate ornamentation of $A$. bacculata is limited to the distal hemisphere. L. triunfensis can also be set apart from A. bacculata by comparing their ornamentation, insofar as the latter species bears spinules that are borne irregularly on the distal hemisphere.

Beyond Gondwana, Auritolagenicula auricula, described by Winslow (1962) as Triletes auritulus from the Lower Mississipian of Ohio, U.S.A., shows some similarity to $L$. triunfensis in size and in the type of gula, but the ornamentation and shape of the auriculae are different.

\section{Lagenoisporites scutiformis \\ Trindade, 1970}

Figure 4 (pictures 1-6) and Figure 5 (picture 3) Samples: GP/3T 2143, 2147, 2156, 2158, 2160b, $2162,2165,2167,2182,2189$, and 2204c.

Description: Megaspores with gula, rounded to oval in polar compression and prolate in lateral compression. Gula pyramidal with acute apex. Trilete rays thick and straight. Arcuate ridges well-defined, confluence between the trilete rays and the arcuate ridges marked by large lateral auriculae. Contact faces psilate, distal surface granulate to scabrate.

Dimensions: a) Equatorial view: 1622 (2070) 2511 $\mu \mathrm{m} \times 1177$ (1584) $1956 \mu \mathrm{m}$. Gula 667 (863) 1111 $\mu \mathrm{m} \times 889$ (1063) $1178 \mu \mathrm{m}$. Trilete rays 600 (765) $933 \mu \mathrm{m}$. Arcuate ridges 800 (1000) $1222 \mu \mathrm{m}$. Auriculae 222 (273) $378 \mu \mathrm{m} \times 133$ (203) $267 \mu \mathrm{m}$.

b) Polar view: Equatorial diameter 1133 (1767) $2022 \mu \mathrm{m}$. Gula $668(689) 711 \mu \mathrm{m} \times 778$ (929) $1000 \mu \mathrm{m}$. Trilete rays 600 (772) $889 \mu \mathrm{m}$. Auriculae 222 (253) $311 \mu \mathrm{m} \times 200$ (222) $268 \mu \mathrm{m}$.
Discussion: The 34 megaspores studied represent $18 \%$ of the total and constitute the second most numerous species. Twenty specimens appeared in lateral compression (Fig. 4, pictures 3, 5 and 6) and 7 in polar compression (Fig. 4, pictures 1 and 2).

The most common dimensions, for specimens in lateral compression, range from 1800 to $2200 \mu \mathrm{m}$ in length (16 specimens) and 1400 to $1800 \mu \mathrm{m}$ in width (14 specimens). The most common equatorial diameter ranges from 1800 to $2100 \mu \mathrm{m}$ (4 specimens).

Based on such characters as shape, dimensions, and exine ornamentation, these specimens are attributable to Lagenoisporites scutiformis Trindade. This species has previously been recorded from Monte Mor (Itararé Subgroup), State of São Paulo, by Trindade (1970); and from S.J. do Triunfo (Rio Bonito Formation) Paraná State, by Arai and Rösler (1984).

As mentioned above, L. triunfensis and L. scutiformis differ in distal ornamentation (baculate and psilate-scabrate, respectively).

As with L. triunfensis, L. scutiformis might also be included in the genus Auritolagenicula, according to the taxonomy proposed by Dybová-Jachowicz et al. (1979), because it shows an anguligula. However, its psilate to scabrate distal ornamentation precludes such reassignment.

Besides, if the synonymy between Lagenoisporites and Auritolagenicula was confirmed, the priority must be given to the former genus, because Lagenoisporites was erected in 1955 and Auritolagenicula in 1979.

Trindade (1970) and Arai and Rösler (1984) alluded to resemblance between Auritolagenicula angulata (=Lagenicula) and L. triunfensis. Distinction between these two species is discussed above. The difference between $L$. scutiformis and A. angulata lies in the nature of the thick exinal ornamentation (psilate in the case of L. triunfensis).

A. angulata has been reported from the Lower Carboniferous of Egypt, North America, and Poland. It is possible that a relationship exists between it and L. scutiformis, but this can be estab- 


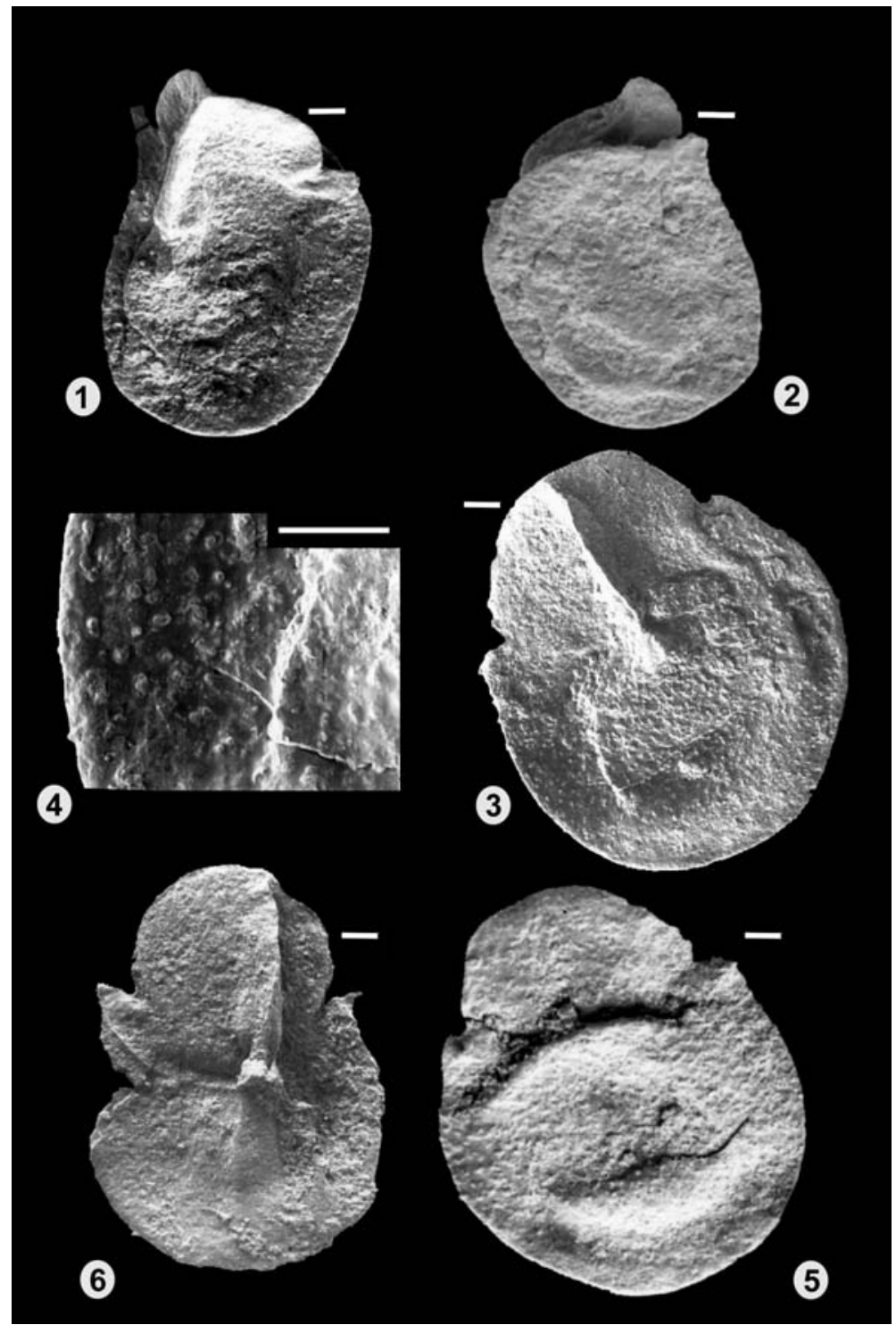

Fig. 4 - Megaspores Lagenoisporites scutiformis: 1. Oblique proximal view (GP/3T 2165); 2. Oblique distal view; 3. Lateral compression (GP/3T 2165); 4. Magnification of fig. 3 showing ornamentation; 5. Oblique distal view of fig. 3; 6. Typical specimen, oblique proximal view (GP/3T 2147). Scale bar $=200 \mu \mathrm{m}$.

lished only on the basis of specimens obtained from intermediate time intervals and localities.

Genus Sublagenicula (Potonié and Kremp)

Dybová-Jachowicz, Jachowicz, Karczewska, Lachkar, Loboziak, Piérart, Turnau and Zoldani 1979

\section{Sublagenicula cf. S. brasiliensis}

(Dijkstra) Dybová-Jachowicz, Karczewska,

Lachkar, Loboziak, Piérat, Turnau and Zoldani 1979

Figure 5 (pictures 4-6).

Samples: GP/3T 2138, 2146, and 2165. 

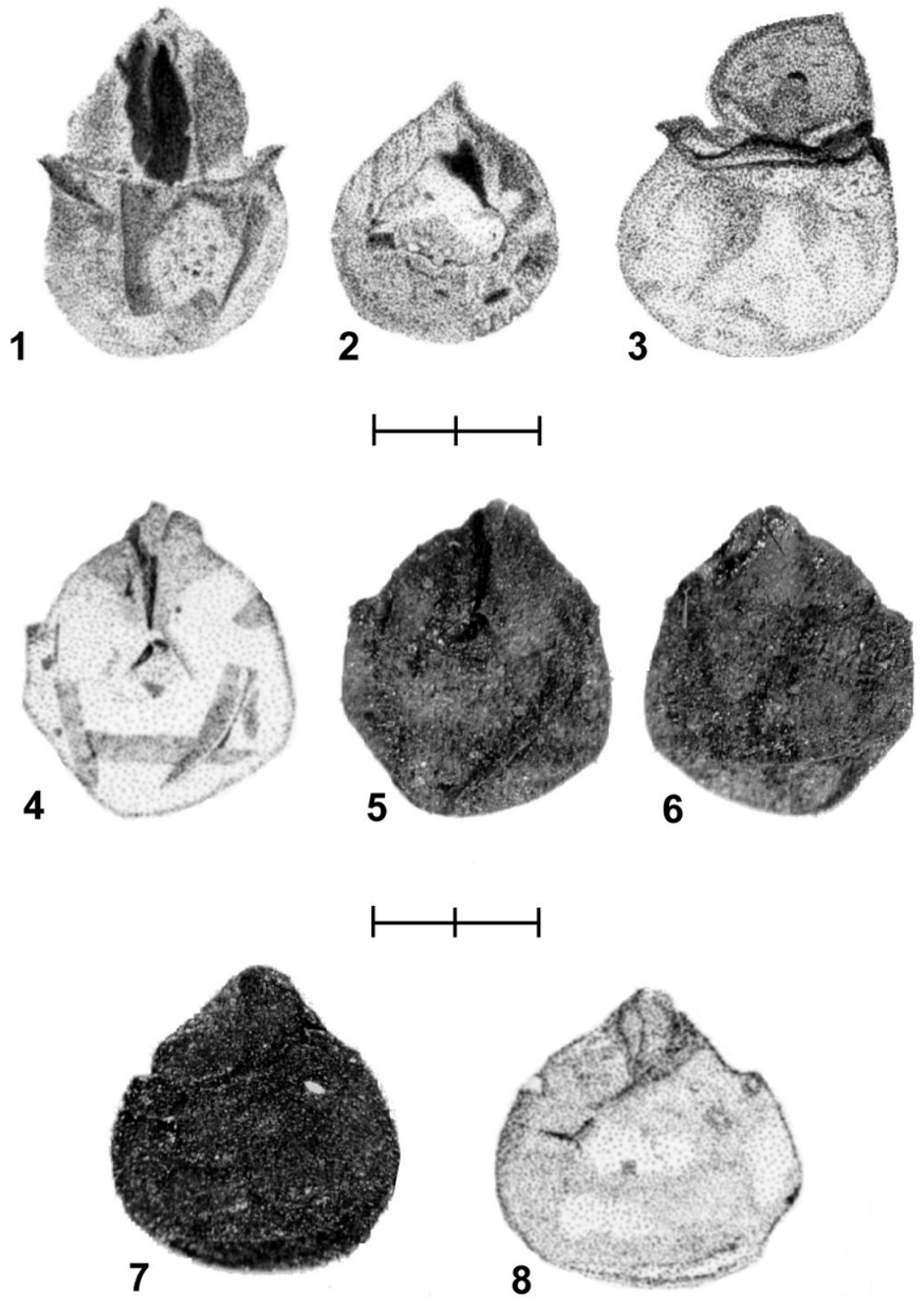

Fig. 5 - Megaspores L. triunfensis (pictures 1 and 2), L. scutiformis (picture 3), Sublagenicula cf. brasiliensis (pictures 4-6), Setosisporites cf. furcatus (pictures 7 and 8): 1. Lagenoisporites triunfensis, lateral compression. (GP/3T 2189); 2. Lagenoisporites triunfensis, polar compression, proximal view (GP/3T 2204); 3. Lagenoisporites scutiformis, distal view in lateral compression (GP/3T 2182); 4. Sublagenicula cf. S. brasiliensis, lateral compression (GP/3T 2147); 5. Sublagenicula cf. S. brasiliensis, oblique proximal view; 6. Sublagenicula $\mathrm{cf}$. S. brasiliensis, oblique distal view; 7. Setosisporites cf. S. furcatus, lateral compression (GP/3T 2147); 8. Setosisporites cf. S. furcatus, lateral compression. Scale bar: $1 \mathrm{~mm}$. 
Description: Megaspores subgulate, prolate in lateral compression. Trilete rays straight. Arcuate ridges poorly defined, their confluence with trilete rays well-defined by small triangular auriculae. Contact faces psilate; distal surface scabrate to psilate.

Dimensions: Equatorial view: 1556 (1850) 2156 $\mu \mathrm{m} \times 1400(1658) 1911 \mu \mathrm{m}$. Subgula 556 (716) $800 \mu \mathrm{m} .844$ (866) $111 \mu \mathrm{m}$.

Discussion: Seven megaspores were studied, all in lateral compression; length 1500-1900 $\mu \mathrm{m}$ (4 specimens). They resemble Sublagenicula brasiliensis (Dijkstra) Dybová-Jachowicz et al. in shape, gula, exine ornamentation, trilete rays, and arcuate ridges. But there are size differences (Table II): the studied specimens are larger than those reported previously from Brazil (Dijkstra 1956, Piérart and Dijkstra 1961, Trindade 1959, 1962, 1970, Cauduro and Zingano 1965, Marques-Toigo et al. 1975), Argentina (Spinner 1969, Archangelsky et al. 1989, Cúneo et al. 1991, García 1995), and South Africa (Pant and Srivastava 1962). Leinz (1940) illustrated megaspores from coal samples of the Rio Carvãozinho (Figueira region) that are very similar to our specimens. It seems unusual that this is the only previous record of these megaspores from the Figueira region.

It is important to note that differences in size may relate to climatic, ecological, or intraspecific variations. Taking into account the fact that $S$. brasiliensis has a broad distribution range, in both space and time (being known from the Lower Carboniferous of Chad, Egypt, and Nigeria and CarboniferousPermian of Argentina, Australia, and South Africa), we prefer to identify the Figueira megaspores as $\mathrm{Sub}$ lagenicula $\mathrm{cf}$. brasiliensis.

Genus Setosisporites (Potonié and Kremp) Dybová-Jachowicz, Jachowicz, Karczewska, Lachkar, Loboziak, Piérart, Turnau and Zoldani 1979

\section{Setosisporites cf. S. furcatus}

(Dijkstra) Dybová-Jachowicz, Jachowicz, Karczewska, Lachkar, Loboziak, Piérat, Turnau and Zoldani 1979
TABLE II

Comparison between dimensions of Sublagenicula brasiliensis from the literature and from Figueira.

\begin{tabular}{l|c|c}
\hline & Length $(\mu \mathrm{m})$ & Width $(\mu \mathrm{m})$ \\
\hline Figueira & $1556-2156$ & $1400-1911$ \\
Brazil (elsewhere) & $575-1530$ & $760-1400$ \\
Argentina & $600-1378$ & $400-978$ \\
South África & $585-1780$ & $458-1425$ \\
\hline
\end{tabular}

Figure 5 (pictures 7and 8).

Sample: GP/3T 2147.

Description: Megaspores subgulate, prolate in lateral compression. Trilete rays straight and smooth. Arcuate ridges smooth. Contact faces psilate; distal surface baculate.

Dimensions: Equatorial view: 1689-1933 $\mu \mathrm{m} \times$ 1667-1867 $\mu \mathrm{m}$. Trilete rays 511-1000 $\mu \mathrm{m}$. Bacula $22 \mu \mathrm{m}$ long.

Discussion: Of the three specimens identified, two are very poorly preserved. The best preserved specimen, from sample GP/3T 2147, is $1689 \mu \mathrm{m}$ and $1667 \mu \mathrm{m}$ in length and width respectively.

The specimens show some resemblance to $\mathrm{Se}$ tosisporites sp., as recorded previously from Monte Mor (Trindade 1970). However, the latter reportedly measures $1800 \times 1600 \mu \mathrm{m}$ and its exine is comprehensively capillate rather than distally baculate. Similarities with Setosisporites furcatus are in shape, type of gula, and exinal sculpture of both hemispheres. Nevertheless, it should be noted that furcate bacula, reportedly typical of this species, are not conspicuous in our specimens. Furthermore, as with $S$. brasiliensis, the Figueira specimens are larger than those reported previously from elsewhere in Brazil (Dijkstra 1956, Piérart and Dijkstra 1961, Pant and Srivastava 1962, Cauduro and Zingano 1965, Marques-Toigo et al. 1975) and from India (Bharadwaj and Tiwari 1970, as Gulatrileites furcatus). They proved to be approximately $300 \mu \mathrm{m}$ longer. 
These Figueira megaspores are clearly attributable to Setosisporites, and are obviously closest to S. furcatus. However, in view of differences in size and exine ornamentation, it is prudent to designate them as Setosisporites cf. S. furcatus.

\section{DISCUSSION AND CONCLUSIONS}

This paper is a contribution to the knowledge of Early Permian megaspores of Brazil. Details are provided concerning their morphology and distribution, especially for the species Lagenoisporites triunfensis and L. scutiformis.

The megaspore flora discussed here originated from a coastal swamp vegetation characterized by lycophytes. Of the latter, Brasilodendrom cf. pedroanum is quite possibly related to at least one of the species of Lagenoisporites. However, the precise botanical affinities can only be established via in situ observation of the megaspores; so far, no suitable (fertile) megafossils have been found.

The Figueira megaspore flora is of low diversity, and is dominated by L. triunfensis. This concurs with the low diversity of the preserved lycophyte megaflora, and is a likely consequence of a somewhat stressed, tide-influenced coastal paleoenvironment.

The notable endemism of the taphoflora, alluded to in previous megaspore research, are reinforced by the present study. Neither L. triunfensis nor $L$. scutiformis is known outside of Brazil, nor even beyond the states of São Paulo and Paraná. Nevertheless, we do not exclude the possibility of finding these species in more meridional localities, because the swampy regions of the Early Permian (typified by the Triunfo Member) characterized the entire paleo-shoreline, extending into the state of Rio Grande do Sul.

Considering the interval between the early and middle Artinskian, related to S.J. do Triunfo (Arai and Rösler 1984), and that between the end of the Sakmarian and the beginning of the Artinskian in Figueira (Ricardi-Branco 1997), it seems reasonable to assume that both $L$. triunfensis and $L$. scutiformis are typical of the middle Early Permian.
Finally, it is interesting to note Piérart's (1962, 1975, 1981, 1984) suggestion that Sublagenicula brasiliensis could belong to the group called "transgressive megaspores" (along with Setosisporites furcatus, among others) that migrated during the Carboniferous from regions close to the glaciation limits to regions subsequently colonized by the Glossopteris Flora.

\section{ACKNOWLEDGMENTS}

The authors wish to express their sincere gratitude to the following: Fundação de Amparo à Pesquisa no Estado de São Paulo (FAPESP) for research support; Compahia Carbonífera do Cambuí for providing samples; Dr. Samuel Branco for illustrations; Dr. Georges Lachkar (Université Paris VI, France) for contributing helpful comments; Professor Geoffrey Playford (The University of Queensland, Brisbane, Australia) for reviewing the manuscript and making linguistic and other amendments; and two anonymous referees of Anais da Academia Brasileira de Ciências for their suggestions.

\section{RESUMO}

No presente trabalho são apresentados os resultados obtidos a partir do estudo sistemático detalhado dos megásporos provenientes das camadas de carvão do Membro Triunfo, Formação Rio Bonito, Estado do Paraná, Brasil. A seqüência portadora de carvão, foi o resultado do acúmulo de matéria orgânica num de sistema deltaico marinho durante o Eopermiano.

Quatro espécies são aqui descritas e ilustradas: Lagenoisporites triunfensis, L. scutiformis, Sublagenicula cf. brasiliensis, e Setosisporites cf. furcatus. Destas, as duas espécies de Lagenoisporites são dominantes. São igualmente discutidas as relações existentes com outras espécies de megásporos, assim como documentada a distribuição temporal e espacial das quatro espécies na Bacia do Paraná.

Palavras-chave: megásporos, Permiano, Formação Rio Bonito, Bacia do Paraná. 


\section{REFERENCES}

Aboarrage M and Yamamoto K. 1982. Projeto Carvão na área de Amando Simões. Relatório Final. DNPMCPRM. v.1, 38p.

Arai M And Rösler O. 1984. Megásporos de São João do Triunfo, Formação Rio Bonito (Permiano). Bol. IG-USP 15: 53-64.

Archangelsky S, Cúneo R and Seonne LV. 1989. Estudios sobre megásporas pérmicas argentinas. I. Sublagenicula brasiliensis (Dijkstra) Dybová-Jachowicz et al. Ameghiniana 26: 209-217.

BHARADWAJ DJ AND TIWARI RS. 1970. Lower Gondwana megaspores - A Monograph. Palaeontographica Abt B 129: 1-70.

Candilier AM, Coquel R and Loboziak S. 1982. Mégaspores du Dévonien Terminal et du Carbonifère Inférieur des bassins D'Illizi (Sahara Algérien) et de Rhadamés (Libye occidentale). Palaeontographica Abt B 183: 83-107.

CARTA do Brasil 1970. - Esc. 1:50.000. Folha Figueira, PR. - SF-22-Z-C-V-3. Fundação IBGE - Instituto Brasileiro de Geografia.

Cauduro AD and Zingano AG. 1965. Mégaspores en argilite silicifié de São Sepé, Rio Grande do Sul. An Acad Bras Cienc 37: 273-282.

Cúneo R, Seoane LV de and Archangelsky S. 1991. Estudios sobre megásporas pérmicas argentinas. II. Sublagenicula nuda y S. brasiliensis de la Cuenca Chacoparanaense, Argentina. Ameghiniana 28: 5562 .

Della Fávera JC and Chaves H. 1998. Growth-faults in the depositional setting of Gondwanic coal, Paraná basin, Brazil. An Acad Bras Cienc 70: 453-464.

Della Fávera JC, Chaves H, Pereira H, Bergamaschi S, Reis CC, Lima M and Pereira SD. 1993. Geologia da área Figueira-Sapopema. Convênio UERJCPRM. 89p.

DiJkstra SJ. 1956. Some Brazilian megaspores, Lower Permian in age, and their comparision with Lower Gondwana spores from India. Mededel Geol Sticht N Ser 9: 5-10.

Dybová-Jachowicz S, Jachowicz A, Karczewska J, Lachkar G, Loboziak S, Piérart P, Turnau E and ZoldANi E. 1979. Note préliminaire sur la révision des mégaspores à gula du Carbonifère. Les principes de la classification. Acta Palaeontol Pol 24: 411-422.

García G. 1995. Palinológia de la Formación El Imperial, Paleozoico Superior, Cuenca de San Rafael, Argentina. Parte 1: Esporas. Ameghiniana 32: 315339.

LeINZ V. 1940. Gênese de carvão no norte do Paraná. In: Carvão mineral de Barra Bonita e Carvãozinho (Estado do Paraná). Bol DNPM 42: 43-65.

Marques-Toigo M, Corrêa ZCS and Herter GG. 1975. Geology and palynology of Candiota coal mine, RS, Brazil. In: Congreso Argentino DE Paleontologia y Bioestratigrafia, 1, Tucumán. Actas... Tucumán: 1975, p. 401-427.

Morrone N and Daemon RF. 1985. Jazida de Urânio de Figueira, Paraná. In: Principais Depósitos MineRAIS DO BRASIL. V.1: Recursos minerais energéticos. DNPM/CVRD. Brasília. p. 133-142.

Pant DD and Srivastava GK. 1962. Structural studies of Lower Gondwana megaspores Part II. Specimens from Brazil and Mhukuru coalfield, Tanganyika. Palaeontographica Abt B 111: 96-111.

PIÉrART P. 1962. Distribution stratigraphique et géographique des mégaspores du Paléozoïque. Pollen et Spores 4: 370.

PIÉRART P. 1975. Systématique, distribution stratigraphique et géographique des mégaspores du Carbonifère et du Permien. In: Congrés International DE Stratigraphie et de Geológie du Carbon, 7, Krefeld: Compte Rendu... v.4, p. 93-102.

PIÉRART P. 1981. Stratigraphical and géographical distribution of Gondwana megaspores. In: INTERNATIONAL Gondwana Symposium, 5, Wellington. Selected papers and abstracts... Wellington: 1981, p. 19-21.

PiÉRART P. 1984. Les mégaspores du Carbonifère et du Gondwana inférieur de l'Afrique et de l'Amerique du Sud. Bull Séanc Acad R Sci Outre-Mer Meded Zitt K Overzeese Wet 28: 155-163.

Piérart P and DiJkstra SJ. 1961. Étude comparée des mégaspores permiennes du Brésil et du Katanga. In: Congrés de Stratigraphie et de Géologie du Carbonière, 4, Heerlen. Compte Rendu... Heerlen: T. II, p. 541-544.

Ricardi-Branco FS. 1997. Tafoflora gondvânica do Membro Triunfo Formação Rio Bonito (Eopermiano), no Município de Figueira, PR. São Paulo. 182p. 
(Ph.D. Thesis. Instituto de Geociências da USP).

SPINNER E. 1969. Preliminary study of the megaspores from the Tupe Formation, Quebrada del Tupe, La Rioja, Argentine. Pollen et Spores 11: 669-685.

Soares PC AND CAVA LT. 1982. Faciologia e potencial carbonífero da Formação Rio Bonito no norte do Estado do Paraná. In: Congresso Brasileiro DE Geologia, 32., Salvador. Anais... Salvador: v. 3, SBG, 1982, p. 1120-1134.

Trindade NM. 1959. O gênero Lagenoisporites no Gondwana brasileiro. Notas Prelim e Estudos, DNPM 112: 1-13.
Trindade NM. 1962. Megásporos gondwânicos da Mina do Leão, Rio Grande do Sul. Notas Prelim e Estudos DNPM 118: 1-22.

Trindade NM. 1970. Megásporos carboníferos de Monte Mor, Estado de São Paulo. An Acad Bras Cienc 42: 459-470.

WinsLow M. 1962. Plant spores and other microfossils from the Upper Devonian and the Lower Mississippian rocks of Ohio. Geol Surv Prof Papers 364: 1-90. 